\title{
Farmer's Household Economy Working on Conflict Areas in the Meru Betiri National Park
}

\author{
Purwanto, S. Andy Cahyono, C. Yudi Lastiantoro, and Nana Haryanti \\ Watershed Management Research and Development Institute of Solo, Indonesia, email: purwanto_fris@yahoo.com
}

\begin{abstract}
ABSTRAK
Konflik lahan hutan di Taman Nasional Meru Betiri (TNMB) merupakan salah satu jenis konflik lahan hutan konservasi di Indonesia. Konflik tersebut terjadi antara TNMB dengan masyarakat yang tinggal di sekitar hutan (Wonoasri, Sanenrejo, Andongrejo, Curahnongko, dan Kandangan), sejak tahun 1998. Tujuan penelitian ini yakni mengetahui sejarah konflik lahan di TN Meru Betiri dan dampak rehabilitasi lahan terhadap pendapatan petani. Penenilitian ini dilakukan pada tahun 2016. Penelitian kualitatif diterapkan untuk mendapatkan informasi sejarah konflik lahan di TNMB dan survey dilakukan untuk mengumpulkan data kontribusi dari kegiatan pengelolaan pertanian di lahan rehabilitasi (area) konflik terhadap pendapatan petani. Konflik lahan di TNMB terjadi karena adanya kekosongan kekuasaan pemerintah pusat pada tahun 1998 yang menyebar ke daerah sehingga pemerintah tidak mampu mengendalikan penebangan hutan dan penyerobotan kawasan hutan yang dilakukan oleh oknum masyarakat. Pada tahun 1999, politisi lokal Partai Demokrasi Indonesia (PDI) mengajukan ke Menteri Kehutanan agar area konflik di TNMB dijadikan usaha tani masyarakat di sekitarnya. Pada tahun 2000, Menteri Kehutanan menandatangani Perturan Menteri bahwa lahan tersebut sebagai zona rehablitasi. Zona rehabilitasi sebaiknya ditanami Multiple Purpose Tree Species (MPTS) dan tanaman semusim dengan sistem agroforestry. Tujuan penanaman MPTS untuk penghutanan kembali dan tanaman semusim untuk peningkatan pendapatan petani. Setelah 15 tahun program diimplementasikan, peningkatan pendapatan petani dari lahan rehabilitasi hanya mencapai Rp. 3,517,100,-/tahun(US $\$ 1=$ Rp. 13.400,-) atau $14,49 \%$ dari total pendapatan petani. Pendapatan dari lahan rehabilitasi menyumbang ke 3 pendapatan petani, disamping sumber pendapatan non basis lahan dan dari kiriman anggota keluarga petani yang bekerja di luar daerah.
\end{abstract}

Kata kunci: konflik lahan, Taman Nasional Meru Betiri, pendapatan petani

\begin{abstract}
Forest land conflict in Meru Betiri National Park is considered as one of the kind of land conflicts in the forest conservation of Indonesia. The conflict has been taking place between MBNP and the people who live around the forest area (Wonoasri, Sanenrejo, Andongrejo, Curahnongko, and Kandangan) since 1998. The purpose of this research is to know the history of land conflict in Meru Betiri National Park and the impact of land rehabilitation on farmer's income This study was conducted in 2016. Qualitative research was conducted to obtain the historical information of MBNP land conflict and the survey was done to collect data of contribution of cultivation activities in the rehabilitation land (conflict area) on the income of farmers. The forest land conflict took place due to the vacant authority of the central government in 1998 which spread to the local government, so the government is not able to control the illegal harvesting of forest resources and forest area encroachment conducted by the public. In 1999, the local politicians of Indonesian Democratic Party proposed to the Ministry of Forestry in order the conflicted area of MBNP can be cultivated by the people around the area. In 2000, The Forestry Minister issued regulations stated that the assigned land is a rehabilitation zone. The rehabilitation zone must be planted with Multiple Purposes Tree Species (MPTS) and seasonal crops by using agroforestry system. The purpose of MPTS planting is for reforestation and the seasonal crops plantation is addressed for increasing the income of the farmers. After implementing the program for 15 years, the income generated from the rehabilitation land only Rp. 3,517,100,- (US \$ $1=$ Rp. 13,400,-) per year or 14,49\% of the total income of the farmers. The income from the rehabilitation land contributed as the third source of incomes $b$ esides the non land-based sources of income and the income from migrated remittance.
\end{abstract}

Keywords: land conflict, Meru Betiri National Park, farmers income

Citation: Purwanto, Cahyono, S.A., Lastiantoro, C.Y. dan Haryanti, N. (2017). Farmer's Household Economy Working on Conflict Areas in the Meru Betiri National Park. Jurnal Ilmu Lingkungan, 15(2), 112-116, doi:10.14710/jil.15.2.112-116

\section{Introduction}

Conflict of forest land conservation took place in Indonesia. The land conflict of Bukit Barisan Selatan National Park (BBSNP) has happened since 2012. It happened due to the government claim that the occupied area by the Semendenese is a part of the BBSNP land. On the other hand, the Semendenese claimed that they have been living in the area since 
1807 (Kompas, December 23rd, 2013). Forest land conflict also happened in Bukit Barisan National Park (BBNP), Nangru Aceh Darusalam. The conflict was pressured by the expansion of private coffee plantation corps to the area of BBNP (Dairiana, 2011). Illegal logging and land purchasing is the characteristics of land conflict in Kutai National Park, Borneo, Kalimntan (Supriyanto, 2013). Another forest land conflict happened in Meru Betiri National Park, East Java (Muyassyaroh, 2013).

Meru Betiri National Park (MBNP) area is a lowland tropical forest ecosystem, in the eastern part of East Java Province, Indonesia. The area stretches from Betiri bay to Mount Meru (from 0 to 1,223 m above the sea level). The ecosystem has a lot of biodiversity of flora and fauna. It is also becomes the habitat of endangered fauna such as: turtles (Eretmochelys imbricata, Chelonia mydas, Lepidochelys olivacea, Dermochelys coriacea, and Lepidochelys olivacea), Bison Or Bull (Bos javanicus), Crab-Eating Macaque (Macaca fascicularis), Javan Tiger (Panthera tigris Sondaicus), Javan Leopard (Panthera pardus), Ajag (Cuon alpinus Javanicus), Leopard Cat (Prionailurus bengalensis), Deer (Cervus timorensis and C. unicolor), Javanese Flying Squirrel (Iomys horsfieldii), Peacock (Pavo muticus), Crested Goshawk (Accipiter trivirgatus), Falco (Falco moluccensis), Rufous-Bellied Hawk-Eagle (Hieraaetus kienerii), Sunda Scops Owl (Otus lempiji), Javan Owlet (Glaucidium castanopterum), Blyth's Hawk-Eagle (Spizaetus alboniger), etc (MBNP, 2014).

According to Krisnadi (2014), 2,733.5 ha of the rehabilitation zone degraded. This happened since forest land plunder in 1998 -1999. In addition, Muyassaroh (2013) stated that farmers who live around the area of Meru Betiri National Park (Wonoasri, Andongrejo, Curahnongko, and Sanenrejo); cut down the forest stand and changed the areas into dry land farming system, in 1998. They call it as thethelan or bibrikan areas. This activity had created conflict between the people around MBNP and the MBNP management since the areas is legally a part of the management area of MBNP.

During 1998-2000, farmers have cultivated seasonal crops such as corn (Zea mays), upland rice (Oryza sativa), soybean (Glycine max), peanuts (Arachis hypogaea), cassava (Manihot utilissima), banana (Musa paradisiaca), etc. Since 2000, MBNP has developed agroforestry system to solve the land conflict. Based on MBNP regulations, farmers are allowed to cultivate the areas with types of trees, herb, fruit trees, and seasonal crops but they are not allowed to cultivate: cassava, banana, and any other kinds of plantation crops (MBNP, 2001).

This paper is an evaluation result on the progress of the agroforestry system implementation in the rehabilitation zone, regardless particularly on the contribution of the rehabilitation zone toward the income of the farmers after conducted the project in 15 years. The objective of this research is to know the history of land conflict in Meru Betiri National Park, the the benefit from the rehabilitation land, and how many its contribution to the income of the farmers.

\section{Method}

\subsection{Time and Location}

This research was conducted from April to December 2016in Wonoasri Village, Tempurejo Sub District, Jember District, East Java Province, Indonesia. The location is adjacent to Meru Betiri National Park (MBNP). In 1999, since most ofthe farmers inWonoasri have cultivated the area of rehabilitation zone, part of MBNP area. The area is 2,733.5 ha.Rehabilition zone in MBNP depicted on Figure 1.

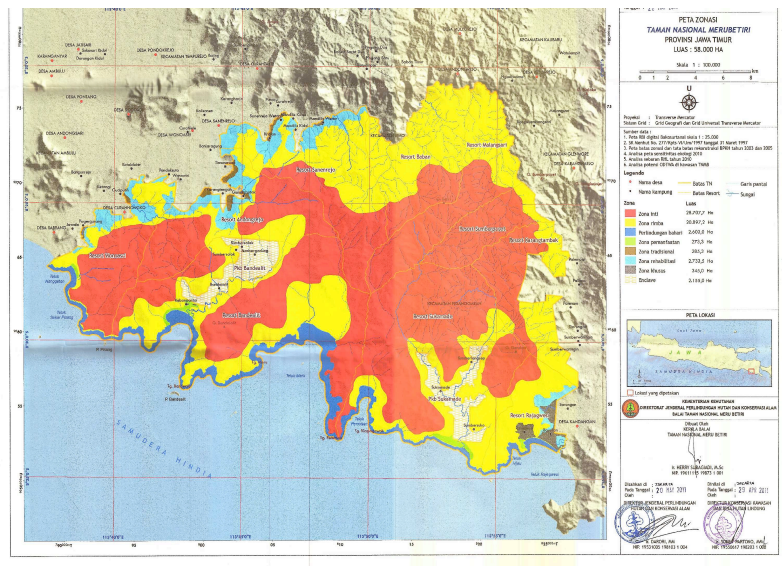

Figure 1. Meru Betiri National Park

\subsection{Research Design}

To obtain information about the history of the forest land conflict and the resolution conducted by stakeholders, snowball sampling has been applied. The main informants are the actors who understand the forest land conflict in the area. The actors are: the head of Wonoasri Village (1 person), the elder farmers (6 people), the board of farmer organization (2 people), the Forest Guard of Perum Perhutani (1 person), the manager of rubber plantation area of Kotta Blater (1 person), and the managers of MBNP (3 people). In depth interviews were conducted to collect the information related to whom (actors), why, when, where, and how the forest land conflict in MBNP happened. Besides, the interviews were conducted to gather informations regarding to the resolutions done by the stakeholders toward the conflict.

To find out on how many the management of the rehabilitation land area has contributed to the income of the farmers, survey method was applied in this research. The population taken for this research was farmers who live in Wonoasri and have cultivated MPTS and seasonal crop in the rehabilitation land of MBNP. About 534 of 1,909 households in Wonoasri have cultivated the rehabilitation zone of MBNP. Random sampling technique was applied in this research (Blalock, 1969). 15\% sampling intencity was applied in this research, therefore, 82 head of the 
households were being interviewed regarding to the cost and income generated from managing the rehabilitation land area.

\subsection{Data Analysis}

The data of the forest land conflict history in MBNP and the resolutions, were analyzed by using qualitative research approach. The analysis of the data was conducted simultaneously by applying data collection, data interpretation, and narrative writing (Creswell, 1994). All of the related informations on the sequence processes before and after the forest land conflict in MBNP and the resolution conducted was arranged into the historical processes of the forest land conflict in MBNP and its resolution.

The formula applied for calculating the income of the farmers is: $\mathrm{I}=\mathrm{Y}_{1}+\mathrm{Y}_{2}+\ldots+\mathrm{Y}_{\mathrm{n}}(\mathrm{I})$; $\mathrm{I}=$ income, $\mathrm{Y}$ $=$ yield $, 1,2, \ldots, 3=$ sources of income. $Y_{i}=B_{i}-C_{i}$ (II); $B$ = benefit, $\mathrm{C}=\operatorname{cost}$ (Singpurwalla, 2013).

\section{Result and Discussion}

\section{A. A Brief History of the Forest Land Conflict and the Resolution}

Forest land conflict in MBNP began to happen in 1998 during the political chaos occurred in Indonesia. The transformation of New Order Era into the Reformation Regime has create vacant authority for several years. This political matter had weakened the authority of the government to control the natural resources which are managed. MBNP is one of natural resources managed by the Indonesian Government through The Ministry of Forestry and by The MBNP Institutes in the local level. When the state government decreasing power, the problem was - in the local level - the natural resources managed by the government were plundered by the people.

In 1999, the local politician of Indonesian Democratic Party (IDP) proposed to the Ministry of Forestry in order to the damaged land in MBNP area can be cultivated by the people around it. Since 2000 , the resolution of the land conflict has begun, in 2000. The Minister of Forestry issued a decree which states that the land is assigned as the rehabilitation zone. The system of agroforestry was implemented in the rehabilitation land zone. The planting of MPTS was addressed for the reforestation and the planting of seasonal crops was addressed for increasing the income of the people around the area.

This project was initiated by the management of MBNP (Government), Non-Government Organizations (KAIL and LATIN), and the people around MBNP. Government and NGO arranged program and provided trees seedling for producing fruits and medicinal products; on the other hand, farmers provided seasonal crop seeds for producing yields for foodstuffs and their household income sources. The land was planted with multi propose tree species (MPTS) and seasonal crops. The kinds of MTPS includes: jack fruits (Arthocarpus hetrophyllus), mangos (Mangifera indika), areca nuts (Areca catecu), kedawungs (Parkia timoriana), petes (Parkia speciosa), etc. The seasonal crops are maize (Zea mais), soybean (Glycine max), purpurea (Purpurea javanica), cassava (Manihot utilissima), green beans (Vigna radiata), peanuts (Arachis hypogaea), etc.

B. Creating Income Sources as Conflict Resolution The sources of the farmers incomes are: 1). Income from rehabilitation land (seasonal crops, fruits and medicine crops), 2). Income from seasonal crops of irrigated field and 3). Income from agroforestry in the government forest lands (teak forest), 4). Livestocks 5). Non land based income (merchant, labor, etc.), and $6)$. Remittances from who work overseas. The income distribution of farmers is described in Figure 2.

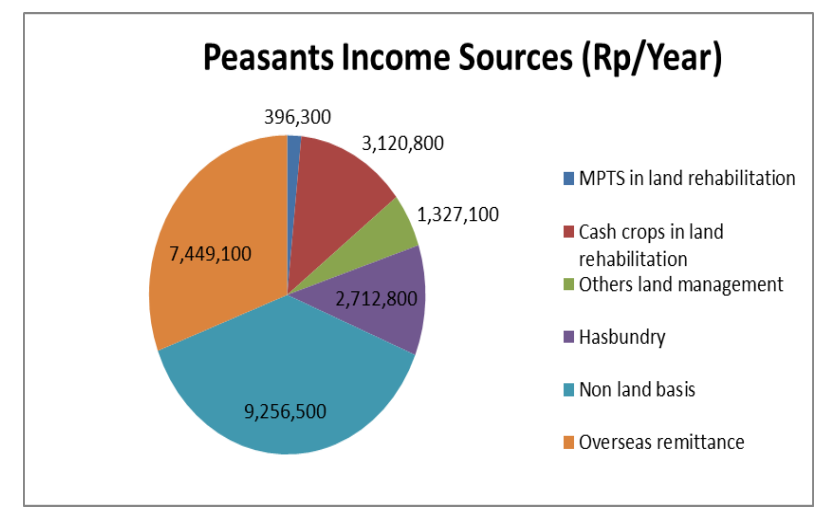

Figure 2. The Total Percentage of Income Sources

The average income of farmers who managed the rehabilitation land is Rp. $24,262,600,-$ /year or Rp. $2.021 .883,-/$ month (US $\$ 1=$ Rp. 13,400). The income generated from the rehabilitation land has contributed $14.49 \%$ of the total household income (12.86\% from seasonal crops and $1.63 \%$ from multiple purpose tree species, MPTS). However, compared to other sources of income, the income generated from managing land rehabilitation is in the third position besides other income, the non land based income and remittances who work overseas. Compared to other researcher's result, Irawan et.al. (2001) reported that the contribution generated from the forest land farming system in BKBH Besali, Padangan Forest Management Unit; was $11.12 \%$ toward household income. Therefore the percentage of the income generated from rehabilitation land in MBNP was higher than the percentage of the income generated from Besali forest land farming system.

Farmers have encountered problems in the rehabilitation land, such as: pest attack (pig and monkeys) and fruits and leaves stealing for the cattle fodders. Pigs attack the seasonal crop and fruit of MPTS. The species of seasonal crops which usually attacked by the pigs are corn, cassava, peanut, green beans, soybean, and purpurea. Besides, monkeys not only attack seasonal crops but also attack jack fruits (Artocarpus heterophyllus). 
The purpose of activities in the rehabilitation land is to develop the forest plantations and to increase the income of the people. However, due to the pest attacking and fruit-leaves stealing, the purpose of the project has not been achieved. Regarding to the matter, the writers suggest to the Manager of MBNP, to reduce the financial loss from the rehabilitation land cultivation, the management of habitat for the wild fauna should be conducted. In the wilderness zone where close to the rehabilitation land should be planted with the local tree species for providing wild pigs and monkeys with the food resources, such as Schima walichii, S. noronhae, Chrysophyllum cainito, Durio zibetinus, etc. If the wilderness zone provides abundance of trees which produce leaves and fruits for the food of fauna, pigs and monkeys will not attack the cultivated seasonal crops and trees. According to Farida (2008), monkeys eat Ficus beyamina fruits and Giganthochloa apus leaves in Bumi Perkemahan Cibubur and Rizaldi, et.al. (2016) reported that monkeys eat $F$. beyamina fruits, Acacia sp. leaves and fruits, Albizia saman leaves, and Ceiba pentandra leaves at Nepa Forest Sampang Madura.

The income from the non land-based has contributed to the highest sources of the income of the people. The non land-based income includes merchant, labor, pension, agriculture workers, plantation workers, etc. The average of income is $\mathrm{Rp}$. $9,255,500,-/ y e a r$. The range of income for each source can be seen on Table 1.

Table 1. The income sources of farmers who cultivate Rehabilitation Land in MBNP

\begin{tabular}{clc}
\hline No & The Sources of Income & Range (Rp./year) \\
\hline 1. & Handymen (labor, such as carpenter, etc) & $1,000,000-21,900,000$ \\
2. & Pensions & $3000,000-23,000,000$ \\
3. & Merchants & $8000,000-25,000,000$ \\
4. & Agriculture and plantation workers & $2,500,000-18,000,000$ \\
5. & Remittances of migrate workers & $5,000,000-16,000,000$ \\
\hline
\end{tabular}

Sources: Analyzed from Primary Data

The income generated from the remittances of people who work overseas has contributed to the income of the farmers Rp. 7,449,100/year. It is in the second level of the income sources. If it is assumed that the sustainability of the natural resources of MBNP is depend on the welfare of the people around the area of MBN, therefore, the government should encourage the people to work overseas. The policy should be given to reduce the land pressure in the rehabilitation area. MBNP could cooperate with the District Government of Jember to train the people who are willing to work overseas.

Another income source is animal husbandry or livestock. The average income generated from this activity is Rp. 2,712,800,-/year. This income is smaller than the income generated from the cultivation in the rehabilitation area; however, this income has the potential to be developed since it is in the fourth level for contributing the household income. The kinds of livestock and the number of livestock ownership per household such as cows (2), goats (5), and chickens (9).

In increasing the people welfare, the campaign to reduce the household expenditure can be implemented. The expenditures can be reduced into more efficient life, except for the basic needs and social needs. Money for buying cigarette is in the third level of the expenditure of the farmers besides the cost for meal and education (Figure 3). The average cost for cigarette is Rp. 1,646,883,--/year or Rp. 137,250,-/ month per household.

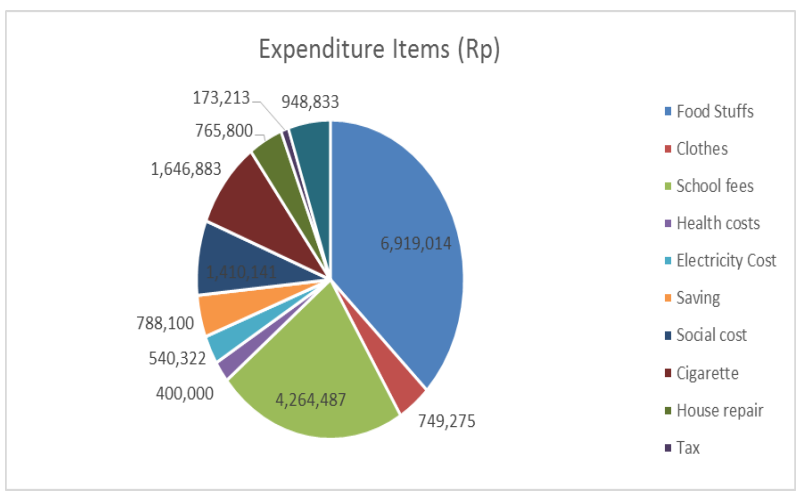

Figure 3. The Expenditure Items of Farmers/Cultivators in the rehabilitation area

In term of economic regional, the south traffic lane nearby the MBNP has been built since the last three years. This road will extend from the easternmost part of the Java Island (Banyuwangi) to the westernmost of Java Island (Banten). This road will open the remote areas in the southern Java as attainable areas. As the consequence, it will effect on the increasing of population and the development of regional economics in the southern part of Java. Moreover, this condition will give the opportunity to the development of the economic regional of the area; however, it will create threat for the natural resources sustainability in MBNP. The local, national, and international tourists will visit and see the natural resources in MBNP, such as the birds watching, the wild fauna watching, jungle tracking, etc. On one side, those activities will increase the income of MBNP and the people around MBNP area but by those activities, 
and without applying the principles of sustainable natural resources management in this area, the natural resources in MBNP will be extinct.

\section{Conclussion}

Forest land conflict in MBNP happened due to the vacant authority of the government in 1998 and this has affecting the local level. In 1999, the local politician of Indonesian Democratic Party (IDP) proposed to the Forestry Ministerin order the damaged land in MBNP area can be cultivated by the people around it. In 2000, The Minister of Forestry issued a decree which states that the land is assigned as the rehabilitation zone. The rehabilitation zone was planted with MPTS and seasonal crops. After being conducted for 15 years, the income of the people by managing the rehabilitation landonly Rp 3,517,100,per year or $14,49 \%$ of the total household incomes. The contribution of the income generated from the rehabilitation landis in the third level besides other income sources which is non land based income and remittance incomes. The problems faced on the cultivation activities in the rehabilitation landare the pest's attack of wild pigs and monkeys and fruit and leaves stealing. To overcome the problems, the management of habitat for pigs and monkeys in the wilderness area where close to the rehabilitation land should be conducted and institutional arrangement for social management of the rehabilitation land should be developed.

\section{Acknowledgement}

First and foremost, Wegive our gratitude, especially to Dr. Nur Sumedi, The Head of Watershed Technology Management Research and Development Center of Solo, Central Java, Indonesia who had given us the opportunity and fund in conducting this research of the forest land conflict resolution at Meru Betiri National Park. Second, we deliver our gratitudeto Mr. Ir. Partono Puruso, MSc., The Head of Meru Betiri National Park Institutes and his staffs, for the permission and support for the success of this research. The third isto Mr. Sugianto, The Head of Wonosari Village, for his permission and for giving us the Wonosari monographic data. Last but not least, we give our gratitude tothe farmers in Wonoasri Village, for their kindness and hospitality responses during the interviews.

\section{References}

Blalock, HM. 1969. Social Statistics. Revised Second Edition. International Student Edition. McGraw-Hill Kogakusha. Tokyo.
Creswell, J.W. 1994. Research Design Qualitative and Quantitative Approaches. Sage Publications. New Delhi.

Dairiana, A. 2011. Land Conflict in Bukit Barisan National Park. Under Graduate Thesis. Forest Management Department. Faculty of Forestry. Bogor Agriculture University.

Farida, H. 2008. Macaca Fascicularis Feeding Activity in Bumi Perkemahan Cibubur. Theses. Department of Biology, Faculty of Math and Natural Sciences. Bogor Agriculture University.

Irawan, E., Purwanto, and T. Corryanti. 2001. Composition of Forestry Farmers Sources of Income: A Case Study at RPH Besali, BKPH Kates, KPH Padangan. Watershed Management Technology Bulletin. Vol. VII, No. 1: 1-14.

Kompas. 2013. Land Conflict Chronologies in South Bukit Barisan National Park. Kompas.Com, 22 December 2013.

Krisanadi, IG. and Suharto. 2014. Poor People around Meru Betiri National Park. Department of History. Faculty of Literature, Jember University. Jember.

MBNP. 2001. Meru Betiri National Park Management Report, Year of 2001. Jember

MBNP. 2001. Meru Betiri National Park Management Report, Year of 2014. Jember

Muyassaroh, I. 2013. Conflict of Interest on the Thethelan Area, Meru Betiri National Park. Faculty of Social and Political Science, Jember University. Jember.

Rizaldy, MR., Tj.Haryono, and U. Faizah. 2016. Feeding Activity of Long Tail Monkey (Macaca fascicularis) at Nepa Forest Sampang Madura. LenteraBio, Vol. 5 No.1, Januari 2016: 66-73. http://ejournal.unes.ac.id/index.php/lenteraBio

Singpuralla, D. 2013. A Handbook of Statistics. Bookboon.com. http://www.e-booksdirectory.com/ details.php?ebook=9440.

Supriyanto, W. 2013. Kutai National Park: Slowly Conflict Resolution, National Park is Sold Slowly. http://www.mongabay.co.id/ 